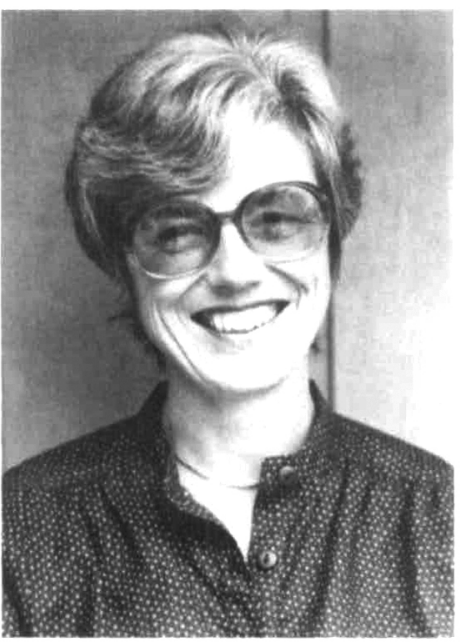

"The energy, creativity and commitment to excellence by everyone associated with the Materials Research Society make it an exciting and rewarding place to work. My commitment is to meet the challenge presented by such a diverse and vibrant group while maintaining my sense of balance and sense of humor."

\section{Geil to be Director of Meeting Activities for MRS}

Merry N. Geil has joined the MRS headquarters staff to serve in the newly created position of Director of Meeting Activities. Approved by the MRS Council in December 1988, the position responds to the need to consolidate the coordination, logistics, and liaison of MRS meetings, which have continued to grow in size and complexity. Geil will provide the principal:MRS headquarters support and liaison for meeting chairs, symposium organizers, and short course planners. She will coordinate the preparation and distribution of the call-for-papers brochures, preliminary programs, final program/ abstract book, and other meeting publications.

Besides supervising on-site meeting operations, her responsibilities also en- compass the coordination of all on-site meeting-related activities. She will coordinate the support provided by MRS headquarters and serve as the principal contact for support provided by meeting contractors for the equipment exhibit and job placement center.

Formerly a meeting planner with The Complete Conference, Geil is well qualified for these responsibilities. A member of Meeting Planners International and the Sacramento Society of Association Executives, she received a $B S$ in business from California State University and has held several supervisory and program development positions. She has been a member and chair for numerous community boards, councils, and committees.

\title{
1988 Von Hippel Award Nominations Sought
}

\section{The Society's Most Prestigious Honor}

The MRS Awards Committee, cochaired by past president Kathleen $C$. Taylor, has announced that nominations are being accepted for the Society's highest award, the Von Hippel Award of the Materials Research Society. The Award is an international hallmark of excellence in the field of materials research, numbering 11 prominent materials scientists as past recipients.

The Award is named for the Emeritus Professor of the Massachusetts Institute of Technology, Arthur von Hippel, whose laboratory pioneered the collaborative, interdisciplinary research that subsequently has taken the identity of "materials science." The Von Hippel Award recognizes those qualities most prized by materials scientists - brilliance and originality of intellect, combined with vision that transcends conventional scientific disciplines. The Award is presented annually by the Society at its Fall Meeting.

Past recipients of the Award are:

Prof. Arthur von Hippel

Dr. William O. Baker

Prof. David Turnbull

Prof. W. Conyers Herring

Prof. James W. Mayer

Prof. Clarence M. Zener

Prof. Sir Peter B. Hirsch

Dr. Walter L. Brown

Dr. John W. Cahn

Prof. Minko Balkanski

Sir Charles Frank

The recipient is selected by majority

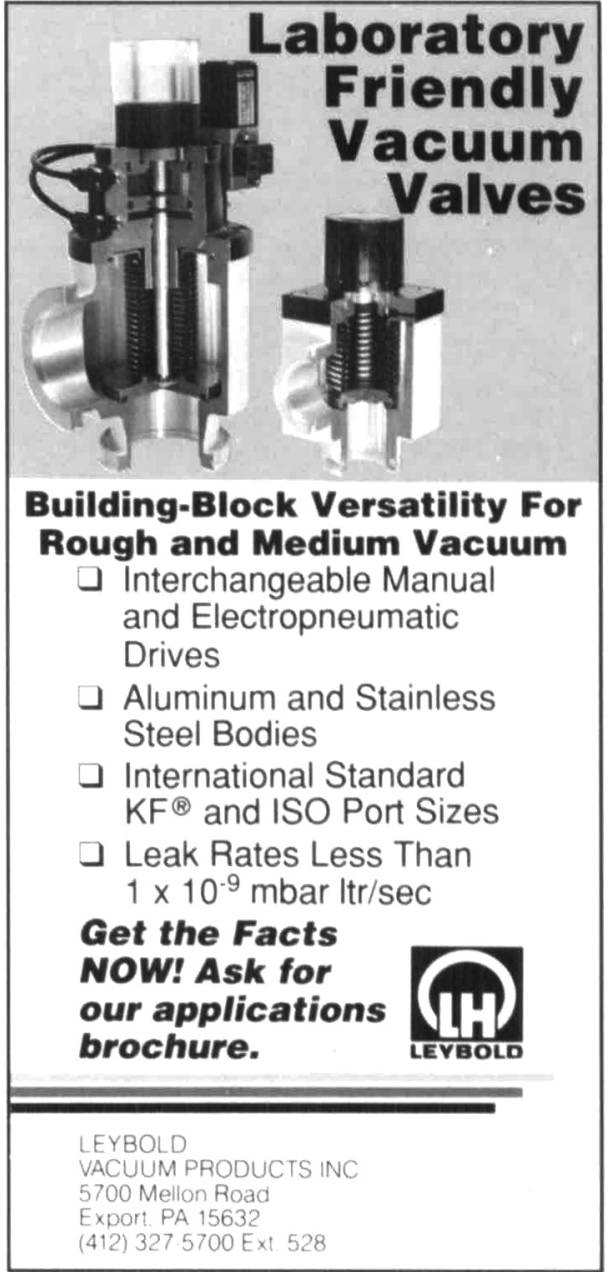

vote of the MRS Council from a slate of candidates that is prepared by the Awards Committee. Nominations should be made to the MRS Awards Committee. Names put into nomination are, in accordance with MRS Bylaws, considered active for three years. Nominations must be made using the Von Hippel Award Nomination form obtainable from MRS headquarters and should be accompanied by supporting documentation.

Send nominations to: Kathleen C. Taylor, Physical Chemistry Department, General Motors Research Laboratories, Warren, MI 48090. 